\title{
IPAL Bukan Lampu Aladdin
}

\author{
Oleh Gede H. Cahyana \\ Dosen Teknik Lingkungan. Universitas Kebangsaan, Bandung \\ Koran Pikiran Rakyat, 20 September 2014
}

\begin{abstract}
Banyak yang menyangka bahwa IPAL itu seperti mesin. Katakanlah semacam "mesin" blender untuk membuat jus (juice). Masukkan buah-buahan (input), tekan knop on, tunggu sambil santai (proses), hasilnya adalah jus segar (output). IPAL tidak demikian. Ia mirip makhluk hidup yang perlu dirawat, diperhatikan, diberi "vitamin", dan kalau "sakit" harus segera "diobati".
\end{abstract}

Anggapan bahwa IPAL itu seperti mesin atau robot yang tidak perlu "kasih-sayang" manusia (baca: operator) adalah keliru, Akibatnya, banyak IPAL yang akhirnya bermasalah lalu gagalolah. Sekadar contoh, nyaris semua IPAL milik rumah pemotongan hewan (RPH) menimbulkan polusi udara, tanah, dan perairan. Sektor industri, seperti pabrik tekstil di Bandung Raya juga sarat masalah. Industri rumahan juga sama, tidak memiliki IPAL. Pabrik besar pun banyak yang tidak ber-IPAL seperti di Cimahi, yang pada September 2014 baru ditindak 30 pabrik.

\section{Bukan lampu Aladdin}

Buruknya kualitas pengolahan IPAL tersebut erat kaitannya dengan pemahaman keliru terhadap teknologinya. IPAL bukanlah lampu ajaib Aladdin yang dengan ucapan sim salabim saja, langsung hasil. Sangkaan keliru ini merebak luas di kalangan dinas-dinas yang memiliki projek IPAL dan kantor atau badan pemerintah yang berkaitan dengan air limbah dan sanitasi. Interaksi kalangan dinas dan penyedia jasa konsultan dan kontraktor atau pengadaan barang \& jasa kerapkali tidak klop (tidak nyambung). Bahkan di pihak penyedia jasanya pun tidak memahami hakikat pengolahan air limbah, baik secara biologi maupun fisikokimia.

Anggapan yang marak beredar, IPAL itu seperti mesin yang siap beroperasi dan berproduksi setelah dipasang (istilah di lapangan: di-install) tanpa keterlibatan manusia (operator). Justru bagian terpenting dalam operasi IPAL adalah peran operator dalam memantau proses di semua unit pengolah di dalam IPAL. Klaim yang menyatakan bahwa IPAL-nya mampu mencapai efisiensi, misalnya 70\%, 80\% dan seterusnya adalah keliru dan menyesatkan. IPAL yang sama, 
mengolah air limbah yang sama, bisa jauh berbeda efisiensinya kalau berbeda pula "perhatian" atau perlakuan operator terhadap unit-unit pengolahnya. Apalagi kalau dibiarkan begitu saja setelah dipasang, lalu "dilupakan" lantaran meyakini bahwa IPAL itu seperti mesin blender atau lampu Aladdin.

Itu sebabnya, hanya sedikit IPAL yang optimal dalam mereduksi polutan. Mayoritas unit proses yang dibuat pun hanya untuk menurunkan konsentrasi zat organik (senyawa karbon) dengan parameter BOD dan/atau COD. Padahal jenis polutannya, selain senyawa karbon itu, ada bermacam-macam. Sayangnya lagi, petugas di dinas, badan, kantor yang berwenang di instansi kesehatan dan lingkungan hanya fokus pada angka BOD dan/atau COD. Malah kebanyakan petugas tersebut dan masyarakat umumnya hanya terpaku pada angka BOD, COD. Sejatinya ada sumber polutan lain yang lebih bahaya bagi lingkungan, yaitu nutrien yang terdiri atas senyawa nitrogen dan fosfat. Dalam silsilah pengolahan air limbah, kedua senyawa tersebut digolongkan ke dalam pengolahan tingkat lanjut (advanced treatment).

\section{Nutrien, si anak tiri}

Di bidang riset dan pengembangan ilmu pengolahan nutrien, berbagai temuan baru bermunculan yang diikuti oleh terapannya di dunia praktis. Apalagi pada masa sekarang banyak produk rumah tangga, hotel, kantor, rumah sakit mengandung nitrogen dan fosfat. Berbagai produk pembersih pun tak lepas dari deterjen yang kaya fosfat sehingga signifikansi nitrogen dan fosfat dalam instalasi pengolahan air limbah cenderung menguat dibandingkan dengan senyawa karbon (BOD, COD). Inovasi dan kreativitas dalam industri makanan dan minuman menimbulkan "ledakan" (booming) polutan N dan P. Pendangkalan sungai, waduk, danau akibat algae (blooming algae) menjadi ancaman bagi sektor perikanan air tawar seperti keramba dan jaring apung termasuk penurunan kualitas sumber air PDAM.

Melihat fakta tersebut, wajiblah petugas di berbagai dinas, kantor, badan di kabupaten, kota, dan provinsi mengawasi IPAL dengan bekal ilmu dan teknologi yang memadai dikaitkan dengan polutan senyawa nitrogen dan fosfat, tidak lagi hanya berpatokan pada angka BOD - COD. Jangan anak-tirikan nutrien karena bisa menjadi the silent killer bagi lingkungan. Kalangan konsultan, kontraktor, dan vendor pun hendaklah memiliki ilmu yang serupa itu agar dapat 
menjelaskan secara betul tentang polutan dari suatu pabrik, kantor, kawasan permukiman, rumah sakit, puskesmas, hotel, dll. Lewat mereka inilah masyarakat akan mulai bertambah ilmunya tentang air limbah dan teknologi pengolahannya sehingga "jargon" semacam IPAL adalah BOD, COD saja mulai berubah, yakni ditambah dengan nitrogen dan fosfat, yang ketiganya bisa diolah secara biologi-lengkap (bioproses komplit) dengan pemantauan rutin oleh operatornya dan tersedia peralatan dan bahan kimia di laboratorium mini internal.

Dengan pola pikir seperti itu maka IPAL yang hanya terdiri atas proses anaerob tidak akan mampu mengolah senyawa nitrogen dan fosfat secara optimal. Bahkan tak mungkin terjadi reduksi senyawa tersebut kecuali hanya sejumlah yang dibutuhkan oleh bakteri dan archaea (nomenklatur baru untuk bakteri anaerob) untuk pertumbuhannya. Itu sebabnya, semua teknologi seperti septic tank, Imhoff Tank, digester, dan banyak lagi nama merek berbahan fiberglass yang dijual komersial di toko tidak akan mampu mengolah $\mathrm{N}$ dan P. Produk itu hanya mampu mengolah senyawa karbon dalam wujud BOD dan/atau COD. Ini pun masih rendah efisiensinya lantaran dibiarkan begitu saja tanpa pantauan rutin. Semua IPAL, sesederhana apapun ia, perlu dirawat dan dicek kualitasnya secara berkala oleh operator, baik yang dipasang di rumah, kantor, hotel, puskesmas, rumah sakit, pabrik maupun kawasan industri.

Selain senyawa nitrogen dan fosfat, masih ada lagi polutan lainnya, yaitu logam berat dan B3 yang sulit diolah secara biologi. Cemaran B3 ini pun telah merusak 415 hektar sawah di Bandung pada September 2014. Kelompok polutan terakhir ini harus diolah secara kimia dengan melibatkan beberapa jenis zat kimia sebagai reagen yang nilai investasi dan biaya O-M-nya jauh lebih mahal dibandingkan dengan bioproses. Pengolahan kimia ini pun mutlak membutuhkan pantauan rutin dari operator qualified, yaitu operator yang memiliki ilmu di bidang proses pengolahan kimia, baik dengan pelatihan maupun sekolah.

Pembaruan informasi tentang jenis pencemar dan teknologi terapannya perlu dimiliki oleh semua orang yang berkecimpung di dalam pengolahan air limbah dan sanitasi. Jika tidak demikian, maka lambat laun IPAL itu akan berubah menjadi monumen, onggokan beton, fiberglass dan pipa belaka. * 